Litteratur

1. Zahl P-H. Informasjonen om mammografiscreening er ikke nøytral. Tidsskr Nor Legeforen 2013; 133: 1557-8.

2. Tretli S, Ursin G. Overdiagnostikk ved mammografiscreening. Tidsskr Nor Legeforen 2012; 132: 1206.

3. Zahl P-H, Strand BH, Maehlen J. Incidence of breast cancer in Norway and Sweden during introduction of nationwide screening: prospective cohort study. BMJ 2004: 328: $921-4$

4. Falk RS, Hofvind S, Skaane P et al. Response to comments by Kalager et al. and Zahl et al. Int J Cancer 2013; e-publisert 3.5.2013.

5. Paci E, EUROSCREEN Working Group. Summary of the evidence of breast cancer service screening outcomes in Europe and first estimate of the benefit and harm balance sheet. J Med Screen 2012; 19 (suppl 1): 5-13.

6. Independent UK Panel on Breast Cancer Screening. The benefits and harms of breast cancer screening: an independent review. Lancet 2012; 380: 1778-86.

7. Citizens' Jury on information for women about breast screening. www.informedchoiceaboutcancerscreening.org/wp-content/uploads/2013/01/ OPM-ICCS-Citizens-Jury-FINAL-REPORT-07012013.pdf (18.8.2013).

Dette er en redigert versjon av et innlegg publisert som rask respons på nett 19.8.2013. http://tidsskriftet.no/article/3041335/

\section{Mammografiscreening - på tide å flytte fokus}

I Tidsskriftet nr. 15/2013 presenterer Zahl nok en gang sine betraktninger rundt mammografiscreening i Norge, der han kommer med påstander om at Kreftregisteret driver bevisst feilinformasjon når det gjelder effekten av screening på brystkreftdødelighet og overdiagnostikk (1). Zahl er tydelig på kollisjonskurs med Kreftregisteret, men det er viktig å få frem at han også er på kollisjonskurs med andre fagmiljøer som jobber med brystkreft og mammografiscreening.

I løpet av det siste året er det blitt publisert studier der man analyserer effekten av europeiske mammografiscreeningsprogram (2), så vel som en stor britisk oversiktsstudie der man blant annet har analysert resultatene fra tidligere randomiserte kontrollerte studier (3). I alle disse konkluderes det med at mammografiscreening nytter. I en nylig publisert kohortstudie fra Norge basert på individdata og 15 års oppfølgingstid, beregner forfatterne en reduksjon i brystkreftdødelighet på $43 \%$ hos kvinner som møter til screening, sammenliknet med inviterte kvinner som ikke møter (4). Disse resultatene er helt i overensstemmelse med resultater fra andre europeiske land.

Nye studier gjort med god metodologi underbygger dermed Verdens helseorganisasjons tidligere konklusjon om at mammografiscreening for 50-69 år gamle kvinner reduserer dødelighet av brystkreft. Dette selv i en tid der både diagnostikk og behandling av brystkreft er blitt mer effektivt enn tidligere.

Norsk Bryst Cancer Gruppe, som er en tverrfaglig gruppe bestående av onkologer, kirurger, patologer og radiologer, konkluderer også med at systematisk mammografiscreening gir en klar reduksjon av brystkreftdødelighet (5). I Nasjonalt handlingsprogram med retningslinjer for diagnostikk, behandling og oppfølging av pasienter med brystkreft vurderes effekten av mammografiscreening på redusert brystkreftdødelighet å være på evidensnivå A (6).

Effekten av mammografiscreening synes således å være solid dokumentert. Fokuset fremover bør nå rettes mot hvordan man kan forbedre behandling av brystkreft $i$ tidlig stadium. Hvis man klarer å utvikle biologiske markører som kan si noe om prognosen til den enkelte brystkreftsvulst, kan det i fremtiden bli mulig å behandle enkelte kreftsvulster på en mindre omfattende måte enn det man gjør i dag. Strålebehandling gjøres allerede med mer avanserte teknikker enn før, med lavere risiko for skade av hjerte og lunger. Mer skånsom behandling vil være en viktig faktor for ytterligere å øke fordelene forbundet med mammografiscreening.

\section{Solveig Roth Hof}

sorohoff@gmail.com

Solveig Roth Hoff (f. 1970) er radiolog og seksjonssjef ved Brystdiagnostisk senter, Klinikk for diagnostikk, Helse Møre og Romsdal.

Oppgitte interessekonflikter: Forfatter er leder i Nasjonal rådgivningsgruppe for Mammografiprogrammet, som er en tverrfaglig, bredt sammensatt gruppe som gir råd om gjennomføring og administrasjon av Mammografiprogrammet.
Litteratur

1. Zahl PH. Informasjonen om mammografiscreening er ikke nøytral. Tidsskr Nor Legeforen 2013; 133: 1557-8.

2. Paci E, Group EW. Summary of the evidence of breast cancer service screening outcomes in Europe and first estimate of the benefit and harm balance sheet. J Med Screen 2012; 19 (suppl 1): 5-13

3. Marmot MG, Altman DG, Cameron DA et al. The benefits and harms of breast cancer screening: an independent review. Br J Cancer 2013; 108: 2205-40.

4. Hofvind S, Ursin G, Tretli S et al. Breast cancer mortality in participants of the Norwegian Breast Cancer Screening Program. Cancer 2013; 119: 3106-12

5. Norsk bryst Cancer Gruppe. Blåboka. www.nbcg.no/nbcg.blaaboka.html (20.8.2013).

6. Helsedirektoratet. www.helsedirektoratet.no/publikasjoner/ nasjonalt-handlingsprogram-med-retningslinjer-for-diagnostikk-behandlingog-oppfolging-av-pasienter-med-brystkreft/Sider/default.asp (20.8.2013).

Dette er en redigert versjon av et innlegg publisert som rask respons på nett 20.8.2013. http://tidsskriftet.no/article/3041335/

\section{P-H. Zahl svarer:}

Ursin, Hofvind og Hoff diskuterer ikke totaldødelighet, men brystkreftdødelighet, som er noe annet. Dette siste er et skjevt endepunkt fordi det ikke tar høyde for at mange kvinner dør av overbehandling.

Kreftregisteret hevder at min forskning er «resultater tuftet på åpenbare metodefeil (2-4)». Deres referanser 2-4 er for det første leserbrev der de hevder at min forsking er basert på gal bruk av metoder (det samme som de sier her), og inneholder ingen dokumentasjon av deres påstand. Referanse nummer 4 er svar på kritikk av en av deres artikler og ikke av min forskning. Det er uredelig å bruke referanser på en slik måte. Jeg har for øvrig en doktorgrad i statistiske metoder og min kritiske forskning av mammografiscreening er publisert i British Medical Journal (1), Lancet (2) og andre vitenskapelige tidsskrifter med høy prestisje. Mine resultater om overdiagnostikk er for øvrig reprodusert av Kalager og medarbeidere i Annals of Internal Medicine i 2012 (3). Det er meningsløst å hevde at disse tidsskriftene publiserer artikler som har åpenbare metodefeil.

Kreftregisteret har derimot publisert mye kritikkverdig forskning. Jeg har nylig publisert en metodeartikkel i British Journal of Cancer om hvordan man skal beregne overdiagnostikk (4). Her viser vi hvordan Kreftregisteret med kreativ bruk av statistikk regner ut overdiagnostikk av brystkreft slik at det blir en tredel av det som leger flest forstår med overdiagnostikk.

Solveig Roth Hoff konkluderer med at «effekten av mammografiscreening synes således å være solid dokumentert». Etter regelmessig mammografiscreening av over 100 millioner kvinner over 40 år diskuterer man fremdeles om mammografiscreening reduserer dødeligheten (5). Dette kan bare fortolkes på én måte: Effekten er så liten at den knapt kan dokumenteres med vitenskapelige metoder. Til sammenlikning trengte man bare å studere 150 pasienter over to år for å overbevise leger om nytten av medisinsk behandling av høyt blodtrykk (6). Ulempene er derimot formidable: Rundt $4 \%$ av alle norske kvinner får nå helt unødvendig strålebehandling i fem uker og antiøstrogenbehandling i fem år som følge av overdiagnostikk.

Til slutt vil jeg kommentere at Kreftregisteret ikke forsvarer sin hemningsløse overdrivelse om at mammografiscreening redder to liv for hver kvinne som blir overdiagnostisert. Dette er propaganda og ikke nøytral informasjon.

\section{Per-Henrik Zahl}

per-henrik.zahl@fhi.no

Per-Henrik Zahl (f. 1961) er dr.med. og lege ved Nasjonalt folkehelseinstitutt

Oppgitte interessekonflikter: Forfatter er betalt av Norges forskningsråd for å evaluere nytten av mammografiscreening.

Litteratur

1. Jørgensen KJ, Zahl PH, Gøtzsche PC. Breast cancer mortality in organised mammography screening in Denmark: comparative study. BMJ 2010; 340: c1241. 